\title{
Vocalist or actor: which one is better prepared to perform in the musical theatre genre?
}

Marina Gennadievna Kruglova*

Anna losifovna Shcherbakova**

Aigul Gareeva**

Alexander Ivanovich Vasilenko****

*Corresponding author, Russian State Social University, 4-1 Wilhelm Pieck str., Moscow, 129226, Russia. ORCID ID: 0000-0001-6256-9380, Email: kruglova6m.g@yandex.ru

**Moscow State Institute of Music named after A.G. Schnittke, 10 Marshala Sokolovskogo str., Moscow, 123060, Russia. ORCID ID: 0000-0001-7371-7211, Email: anna.i.shcherbakova@yandex.ru

***Russian State Social University, 4-1 Wilhelm Pieck str., Moscow, 129226, Russia. ORCID ID: 00000001-7019-6158, Email: Gareeva.Aigul1@yandex.ru

${ }^{* * * *}$ Moscow State Institute of Music named after A.G. Schnittke, 10 Marshala Sokolovskogo str., Moscow, 123060, Russia. ORCID ID: 0000-0003-3845-3585, Email: Vasilenko.A.I2@yandex.ru

DOI 10.12975/rastmd.2021939 Submitted October 17, 2021 Accepted December 20, 2021

\section{Abstract}

The present study aims to research and compare the process of the development of stage skills in music and theater college students and vocal-performance skills in future actors to identify the most effective model of vocational training of musical actors which appears to be upto-date and in demand due to the development of the sphere of culture and entertainment, as well as increased competition among musical theatres and musical actors. The object under study is the process of the development of stage skills in students of musical and theater and acting colleges in the context of professional requirements for musical actors. The study compares the processes of professional realization and the development of stage skills in future musical theater actors and the training of actors in vocal performance to prepare them for creative work in the genre of musicals. The scientific novelty of the study lies in the identification of the specific characteristics of vocational training of future musical theatre actors, the identification of the specific characteristics of stage skills development in future musical actors, and the formulation of major professional requirements for training future actors for work in musical performances. The practical significance of the work is due to the fact that the study results can be used by teachers to improve the vocational training of musical actors, as well as by theater managers and producers in the selection of artists to participate in musicals.

\section{Keywords}

vocational training, future musical theatre actors, musical performances, stage skills. 


\section{Introduction}

The number of people willing to devote themselves to stage professions grows in Russia every year (Babiakina \& Babiakina, 2018; Klabukova, 2016). Variety and academic singer, actor of musical and dramatic theater, ballet dancer - this is only an incomplete list of specialties that can be obtained in colleges of culture and art. The main objective of these educational institutions is the professional realization of future masters of stage and the development of competencies allowing them to engage in acting in the future. The foundation of training of a future actor is the development of stage skills and the ability to transform in the process of creating a stage image. However, a musical actor also requires professional vocal performance training.

\section{Educational Task}

The development of educational programs to train musical theater artists is a difficult task since aside from acting skills, they use professional singing in their work. In musical theatre, vocals and dancing are not of secondary importance (as is the case in drama theatre) but ensure the transmission of the artistic image of the play. Stage skills manifest in musical theatre actors especially vividly in musical plays. This genre embodies a synthesis of

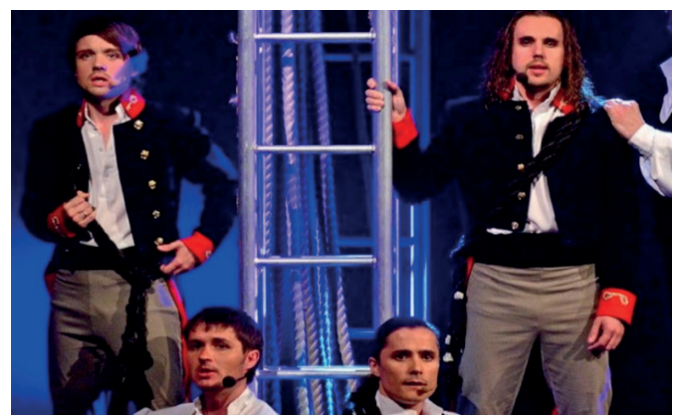

Figure 1. Musical "Juno and Avos" by A. Rybnikov, Moon Theater (2019) vocals, acting, stage speech, and dance, therefore, a musical actor creates their role through not only dramatic art but also the ability to sing and dance professionally (Chaika \& lushchenko, 2020).

Training a musical actor is the process of creating a versatile actor and vocalist in a single person whose activities are very demanding, the requirements including (Andrushchenko, 2011): impeccable vocals, the synchronization of singing and movement, speech and singing skills, body language, pronounced artistry, and high mastery in acting. Therefore, the vocational training of such an actor is a multifaceted process in which the combination of vocals, dance, and acting is aimed at meeting the dramaturgical objectives of a musical play.

Russian musical plays of 2010-2020 (Figure 1 , Figure 2) often involve either dramatic actors with proper vocals or academic vocalists with an appropriate singing style. College educational programs emphasize either the art of acting or vocal performance. At times, pop singers who also lack any special vocal or acting training are invited to perform. All of these factors not only reduce the level of a musical but also hinder the further development of this genre in Russia.

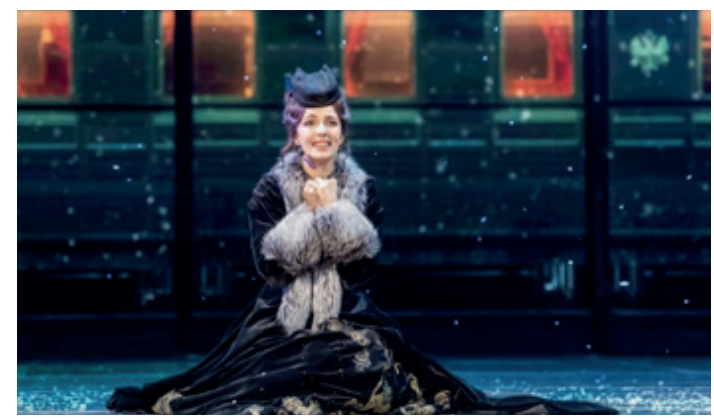

Figure 2. Musical “Anna Karenina” by R. Ignatiev, Moscow Operetta (2020) 
Meanwhile, not all musical actors achieve great creative success in Russia. Therefore, the study and comparison of the development of stage skills in music and theater college students and vocalperformance skills in future actors to identify the most effective model of vocational training of musical actors appear to be up-to-date and in demand due to the development of the sphere of culture and entertainment, as well as increased competition among musical theatres and musical actors.

\section{Literature review}

The methodological basis of the study is created with the works of researchers and specialists in the spheres of musical theatre (M.S. Voznesenskaia, V.V. Usiv, A.A. Chaika, S.S. Aksenova), theatre and vocal pedagogy (I.F. Zimina, B.A. Kotomin, S.V. Mindrin, V.V. Starodubtsev, M.V. Pereverzeva), the technology of pop and jazz vocals (A.V. Antipova, O.-L. Mond, A.A. Polyakova), and professional training of musical actors (E.lu. Andrushchenko, E.P. Babiakina, A.V. Klabukova, T.A. Komarnitskaia, N.lu. Ponomareva, G. J. Feist, M. J. A. Hargreaves, M.V. Pereverzeva).

In research, an actor in a musical is viewed as a universal performer in contemporary art (Andrushchenko, 2011; Zimina \& Novgorodtseva, 2019), a musical actor is referred to both as a "singer-actor" (Voznesenskaia, 2017) and an "actorvocalist" (Poliakova, 2011), the indicators of professional success of a musical actor (Mond, 2011) and the specifics of an actor's work on a part in a musical (Chaika \& lushchenko, 2020; Usov, 2013) are identified, meanwhile, special attention is paid to the specifics of the development of vocalists' stage skills in universities of culture (Klabukova, 2016; Kotomin, 2007) and acting skills in music universities (Mindrin \& Sukhanova, 2017; Ponomareva, 2015), the specifics of learning in music and theatre colleges (Babiakina \& Babiakina, 2018; Komarnitskaia, 2020; Starodubtsev, 2011), the development of artistic and musical abilities (Feist, 2019; Hargreaves, 2003; Pereverzeva et al., 2020a), and the study of modern music (Aksenova et al., 2020; Pereverzeva et al., 2020b).

\section{Research Hypothesis}

The proposed study hypothesis suggests that the model of training a vocalist in acting demonstrates greater effectiveness compared to the opposite model of training an actor in the vocal arts due to the specifics of professional requirements for musical actors.

\section{Methods}

\section{Research Design}

The study was carried out in 2020-2021 in six music colleges and theaters in Moscow (the Moscow Musical Theater, the Operetta Theater, the Moscow Palace of Youth, the Mossovet Theater, the Taganka Theater, Izmailovo Concert Hall, Crocus City Hall, and the Moscow New Drama Theater).

The study was carried out based on theoretical and practical methods: analysis of curricula, analysis of reviews and journalistic articles, data collection from personnel departments of Moscow theaters, interviews with theater audiences, observation of performances of musical artists, analysis of the content of disciplines and practical classes of music and theater students at Moscow's music and theater colleges. 
Vocalist or actor: which one is better prepared to perform in the musical theatre genre?

\section{Data Collection Tools}

Tablo 1. The research objects were the following musicals staged in theaters in Moscow (Russia)

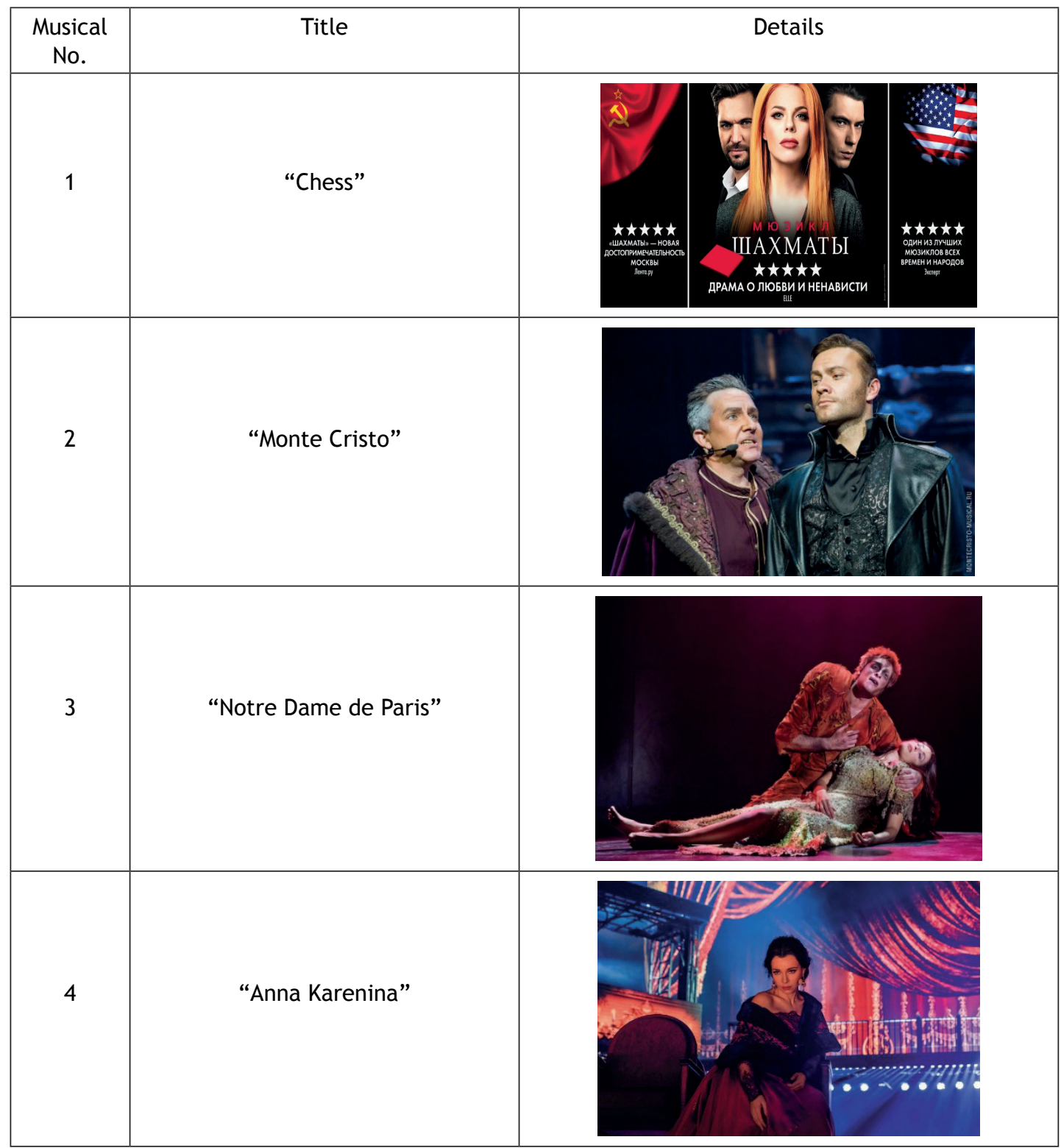




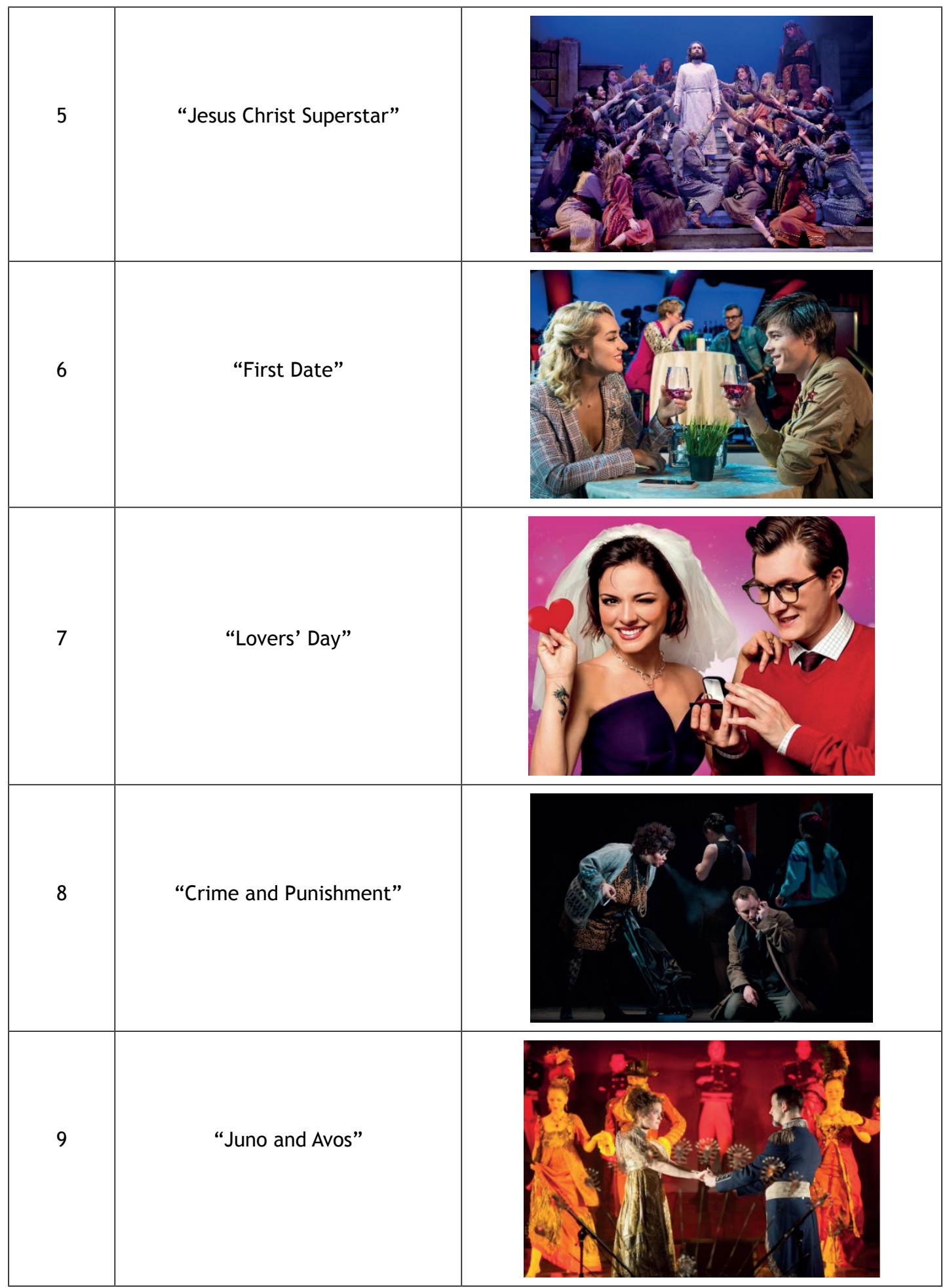


Vocalist or actor: which one is better prepared to perform in the musical theatre genre?

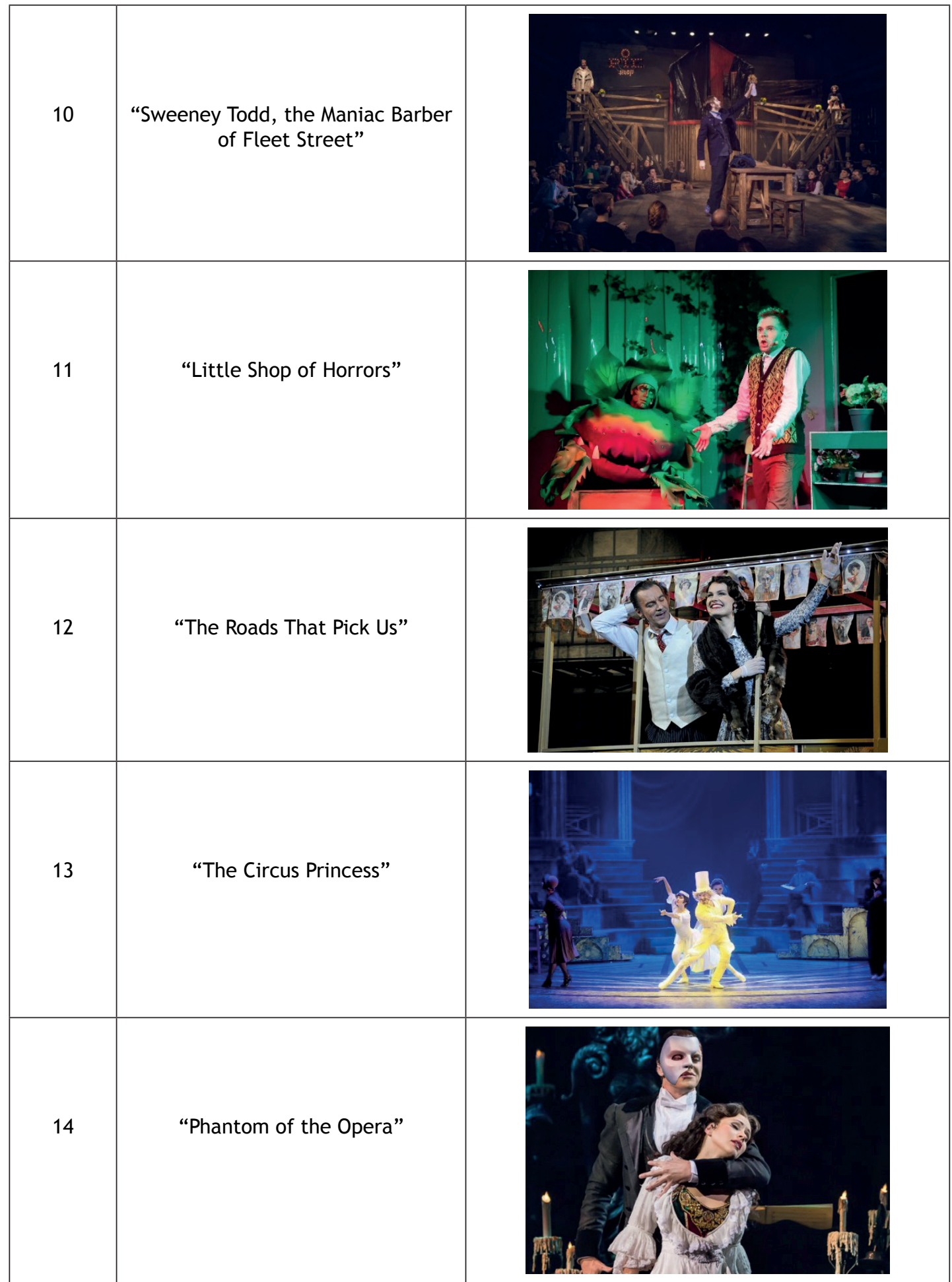




\begin{tabular}{|c|c|c|} 
"Prime Time" \\
"The Strange Story of Dr. Jekyll \\
and Mr. Hyde"
\end{tabular}

\section{Data Analysis}

Statistical methods used to identify the ratio of the artists trained as musical theater actors (that is, actors who have obtained vocal-performance skills) and as pop vocalists (that is, singers who have developed acting skills); the analysis and evaluation of musical actors' performance quality in scientific literature and the press over the past 5 years; generalization of pedagogical experience in professional training of actors and vocalists across the past 5 years.

\section{Results}

Theme 1. Results of the study of educational programs and practical lessons

The analysis of curricula and the content of disciplines and practical lessons of students from 6 music and theatre colleges in Moscow allows revealing the specifics of training of musical actors, specifically the ratio of lessons on vocals for actors (the "Theatre and Film Actor" specialty) and lessons on acting for vocalists (the "Musical Theatre Actor" specialty).
Unlike the "Singer, Pop Artist" and "Drama Theatre Actor" specialties, the "Musical Theatre Actor" specialty requires special professional training. Considering the advancement of the musical genre in Russia and the growing requirements for the quality of musical theater plays, there is a need for specialized profile education accounting for the specifics of this particular musical and theatrical genre. We provide a comparative characteristic of the preparation for performances in the musical genre for a pop singer and a dramatic actor.

To be able to create an artistic image in a musical, in educational institutions, vocalists develop their acting skills while actors develop vocal performance skills. Meanwhile, an actor needs to be able to move well, dance, speak expressively, have a well-trained raised singing voice, etc. The training programs provided by secondary specialized and higher education institutions imply a complete immersion of a future actor into the profession. Acting, stage speech, stage 
movement, dance, and vocals are the disciplines that are studied throughout the entire period of study and form the foundation of education in musical and theatrical performance which synthesizes different types of art. Acting, dance, and stage movement and vocals are obligatory disciplines both in colleges training pop singers and in the institutions training future actors.

The curricula of music and theater colleges and universities of culture and art specify the learning objectives for future vocalists and actors that include the use of the available means of artistic expression to reveal the character of the part, identifying the genre-related specifics of the play in the part, and understanding the objectives of the part and striving to meet them in one's performance. As a result of the "Acting" discipline, vocalists master K.S. Stanislavsky's acting system, the method of working on a stage image, the stages of working on a part in a play, the ability to identify the precisely fitting speech characteristic of the image and work on the part, and to embody the role in the creative process of experiencing based on K.S. Stanislavsky's system (Klabukova, 2016; Usov, 2013).

The fundamental principles of K.S. Stanislavsky's system are based on understanding the fact that an actor has to live and not play on the stage. Everything has to be natural and simple in an actor's stage performance. This requires activating an actor's natural human essence that would allow them to carry out their creative work organically. The primary objective of actors and directors is being able to convey the thoughts and feelings of the author of the work on stage. Stage speech serves as one of the main means of the theatrical embodiment of the dramaturgical idea of the work. The skills of acting speech are developed as a part of the "Stage speech" discipline that involves voice and breathing training and developing proper articulation, correct pronunciation, and intonation. The technique of stage speech is a vital element of acting. It is associated with the soundness, flexibility, "flow", "readability", and volume of the voice, the development of breathing, the clarity of word pronunciation (articulation), and intonational expressiveness (Poliakova, 2011; Antipova, 2019).

As a part of the stage speech course in any music and theatre educational institution, a student also masters the ways of working with literary dramaturgical material, the basics of phonetics and orthoepy of the Russian language, the techniques used in the art of stage speech to make it more expressive and persuasive. In addition, actors and vocalists master the different types of speech character and speech tempo-rhythms, the different ways of analyzing artistic texts practiced in theatrical schools and theaters, and the basics of the theory of poetry (Kotomin, 2007).

It is no coincidence that the "Stage Speech" discipline serves as a continuation of the "Acting" discipline that is the main component of all theatre educational programs since word as one of the leading means of expressiveness for an actor has to serve the part expressing the necessary states and moods, the inner world, and the character's social, psychological, and everyday features. 
The actor's body must also comply with the part they are playing, respond to the conditions dictated by the objectives of the production, and convey emotions and feelings equally as much as the other means of expression. Moreover, an actor on the theatrical stage very often has to perform complex plastic tasks that require having a good physical form and learning stage movements and choreography.

The phrase "stage movement" typically refers to an actor's ability to convey the feelings, emotions, actions, and intentions of their character through body movements. Such a definition can be considered legitimate. However, it should be borne in mind that "stage movement" also comprises the totality of movements of all actors present on the stage, that is, the plastics of the life of the theatrical performance dictated by its atmosphere (Voznesenskaia, 2017). Stage combat with elements of stuntman skills and stage fencing are also part of this discipline. Any performance shows many examples of the implementation of all these skills. An actor of modern theater, including musical theater, must master not only the internal but also external techniques of stage performance.

For this reason, theater and music colleges and universities give high priority to the development of plasticity of a future actor. Along with "acting", "stage movement", and "stage speech", the importance of "dance" is also fairly high. Dance not only straightens the body but also opens up movements, makes them broader, gives them certainty and completeness which is highly important for a professional artist since shortened, squeezed gestures are not stage-appropriate. The dance is enriched and concretized by the costume, theatrical props, and peculiarities of the stage. The organization of the dance in time is subject to the laws of the given musical system as it is measured by the same durations as music (Pereverzeva et al., 2020a).

The singing voice of a musical theatre actor is a vital component of their profession. Professional training of a vocalist for work in a musical is primarily an issue of musical (vocal) education. It has to be noted here that modern state music and theater educational institutions both in secondary and higher education have very few departments and courses deliberately training specialists in this profile. The established group of successful and famous actors in musical theatre is predominantly composed of either drama theatre actors with vocal skills or professional singers fond of theatrical plays.

In recent decades, musical theatre (especially the theatre of musical) has had a great influence on performance technique and the method of teaching vocals in the global pedagogical practice. It had become more evident that classical vocal education and "academic" voice training do not always meet the requirements of modern musical performance and only additional mastery of the technique of singing in the socalled speech position and various vocal styles (rock vocals, belting, screaming) can allow a vocalist to be competitive in this genre (Poliakova, 2011).

Vocals serve as the primary means of expressiveness in modern musical theatre. The explanatory note to the working 
curriculum for the "Vocals" discipline at the Russian University of Theatre Arts "GITIS" for the "Musical Theatre Actor (musicals)" specialty states that vocals as the leading means of teaching perfect mastery of one's voice are one of the main disciplines determining students' professional training implies the development of students' technical vocal skills to the degree required for further work of future specialists (Starodubtsev, 2011).

The main goals of the program include the implementation of the professional skills obtained in the course of learning in theatrical plays and concert performances, as well as the development of the culture of vocal performance and artistic expressiveness. The objectives of the program include ensuring that students develop the skills of a deliberate approach to producing and managing their voice, master the basics of proper vocalization within a certain range and tessitura, obtain the skills of pure intonation, natural timbre, freedom of singing breath, and clear articulation in performance, master the intonation and rhythmic and artisticperformance difficulties inherent in the pedagogical vocal repertoire, develop the skills of independent analysis of the artistic and technical characteristics of vocal pieces for further improvement of their performance skills, obtain the professional skills of performing in an ensemble, as well as learn to comprehend and disclose the artistic content and style of the performed musical piece (Aksenova et al., 2020).

The development of the singing skills of a music and theatre college student has to rely on a diverse repertoire including both classical vocal music and folk songs and the best examples of modern pop music and arias from well-known musicals. It is also important to note the importance of stage practice organized as a part of training. This is the easiest and most reliable way to consolidate the acting and vocal skills learned in class. It is common knowledge that the stage is the best test of an actor's competence. For this purpose, music and theater colleges and universities typically have their own theaters with students participating in the plays.

Thus, the main purpose of training is preparing a highly qualified specialist, a musical theatre actor, for professional stage performance in other words, for performing roles (parts) in musical performances (musicals) (Mindrin \& Sukhanova, 2017).

\section{Theme 2. The results of} observation, the audience survey, and the analysis of publications Analytical observation of musical actors' performances in Moscow theaters and a survey of the audience after viewing the musicals including the assessment of the actors' acting and singing shows that the actors who performed more expressively on the stage of musical theaters are the ones with basic training in vocals and not acting.

The audience survey is composed of two simple questions: which lead singer did you like the most and why? All survey results are presented in Figure 1. 


\section{Which lead singer did you like the most and why?}
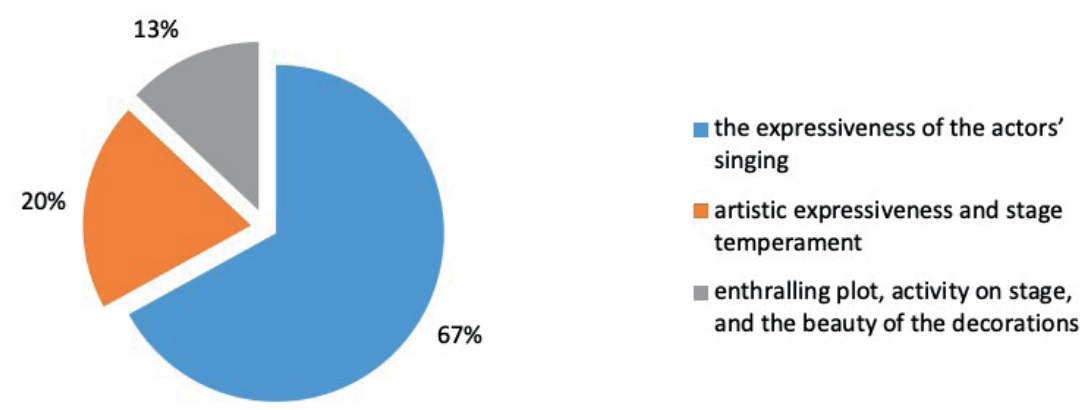

Figure 1. The audience survey results

Thus, we can conclude that it is vocal training that has the utmost importance in the training of musical actors since musicals represent, first and foremost, the musical theatre genre which means that a vocalist can cope with the artistic tasks on a higher professional level compared to an actor who had vocal training as a part of their education. Moreover, the vocational training of students in music and theatre universities is more conducive to the advancement of a musical actor's mastery compared to the training of film and theatre actors.

The majority of actors in theater troupes have primarily a professional vocal education while the minority have education in acting with additional vocal training received in the educational institution which also supports the proposed hypothesis. Figure 2 shows the troupe composition of the capital's theaters.

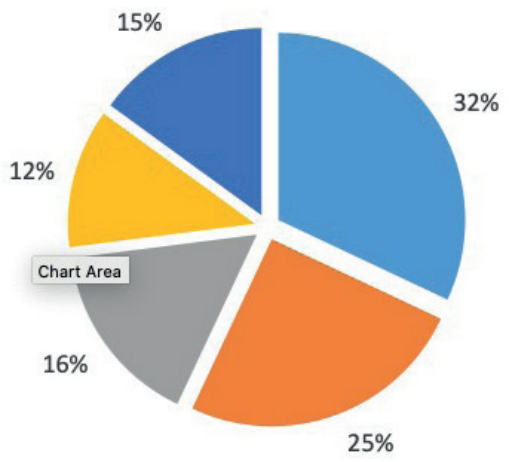

$$
\begin{aligned}
& \text { uraduates of music colleges and } \\
& \text { universities } \\
& \text { m graduates of educational } \\
& \text { institutions of culture and art } \\
& \text { graduates of faculties of music } \\
& \text { and drama } \\
& \text { graduates of faculties of acting } \\
& \text { = professional pop singers without } \\
& \text { special training }
\end{aligned}
$$

Figure 2. Moscow theater troupes

The analysis and summarization of scientific and critical articles (reviews) and press statements on the quality of musical actors' performances over the past 5 years demonstrates that high praise is awarded primarily to professional singers and not actors whose singing strengths and weaknesses are noted while acting abilities fade into the background. However, it should be noted that the overwhelming majority of reviews and journalistic articles (we have analyzed about 30 articles in popular magazines and Internet sources concerning the 
staging of musicals in Russia in the 20102020s) are devoted to well-known artists, the so-called "stars" of the stage, and actors who draw the audience's attention with their participation in musicals as guest "stars". Professional singers, on the other hand, are covered by scholarly studies of their work including their roles in musicals (Voznesenskaia, 2017; Mond, 2011).

Finally, the summarization of pedagogical experience in the professional training of actors and vocalists over the past 5 years allows us to conclude on the effectiveness of programs training vocalists for creative work in musical theater and the lack of vocal training in theater and film actors who also often become performers of parts in musicals.

\section{Discussion}

The obtained results of the study indicate that the main difference between the training of a dramatic actor or a pop singer and that of a musical theater actor lies in the fact that, when performing on stage, a musical actor has to have equal mastery of acting in its best traditions and vocal technique at its highest level and have sufficient choreographic and stage movement training. They are required to exist in the space of a musical play harmoniously while conveying the necessary emotions corresponding to the part they are playing through singing, the voice in dialogues, and body in dance and all manifestations of acting (both external and internal) to organically fulfill the director's assignment.

In short, the development of stage skills in future musical actors has to take place in direct proximity to the musical itself.
We believe that to master these skills, a student has to have a strong desire to perform on stage in this specific genre, therefore, a future musical theatre actor had to have correct ideas about the specifics of a musical actor's work, deliberately train themselves for this activity, independently study the best world examples of musical plays, and listen to recordings of the most famous and recognized performers in this genre. It is necessary to regularly attend productions of musicals and analyze them, making attempts to penetrate the essence of each character and trying on particular roles.

The beginning of the development of stage skills in a future actor is ensured by the mastery of a set of professional disciplines - "Acting", "Vocals", "Dance", "Stage movement", and "Stage speech" necessary for work in a musical theatre. The training of musical actors and dramatic theatre actors is based on the unified state educational standard, therefore, the requirements for the "Acting" discipline are the same for students in different professional orientations. However, the training of musical actors has a significant specific feature: the development of stage skills is based on musical training. Therefore, music is a necessary component of every professional discipline which is logical since music lies at the basis of each musical play (Pereverzeva et al., 2020b).

The initial acting skills are acquired in work on the simplest educational sketchestrainings that have to be accompanied by music and its metrhythmic basis already at this stage as music in this genre is the most powerful exciter of the stage 
action. Moreover, work on the image has to be accompanied by the analysis of songs from the point of the hidden motifs and intonations that can serve as a basis for the stage image of the character. The development of the skill of stage interaction with other actors in work on educational sketches is an important part of the development of stage skills and a basis of future stage action. A student has to learn an emotional, sensual attitude to their partner on stage which is promoted by the nature, tempo, and rhythm of the music being played during the work on the sketch.

The initial part of learning also involves understanding that a musical play is a drama written through music. Thus, a vital part of training a future musical actor is the work on musical sketches in which acting is closely intertwined with vocals. As part of this training, a student develops the skill of effective singing on the material of a song, romance, or aria with a search for expressive means of musical and stage image. The appearance of a character is also created - their external characteristics in direct association with the musical essence, plasticity, and characteristics of speech. In addition, a future musical actor trains their skill of simultaneous and separate memorization of music and text.

The next and more challenging stage of training is work on specific scenes from a musical and dramatic work. It implies the practical mastery of musical material that combines music and drama created by the authors - the composer and the librettist. Having mastered and trained this material, a student can proceed to the creation of a musical stage image.
Students learn to identify the plotline of the play and its importance for disclosing the stage image, to understand the genre and stylistic features of the "core" of the part, to reveal the logic behind their character's thought. All of this has to be tied to the musical characteristics of the performed image to make the perception of it holistic. It is also advised to thoroughly study the music and libretto from the historical perspective to gain an understanding of the time when the work portrayed in the play was created.

In the process of creative interaction with the director in the process of creating the stage image, students develop the skill of analyzing the part in the context of the entire musical play considering the plan of the author and the director. They learn to independently identify the super-task and the cross-cutting influence of the role (part), to determine its psycho-physical content, to organize the behavior of the character in accordance with the music. At this stage of training, beginner actors are already tasked with stage reincarnation which involves immersing themselves in the personality of their character: their feelings, attitudes, and thoughts.

The results of the present study indicate that the problem in the staging of modern Russian musicals is that all of the singing actors taking part in the mass scenes are typically professional dancers or actors and not singers. Meanwhile, theatre and film actors and dancers typically only learn vocal-performance skills at the beginning of their study at the university meaning that they only spend two to three years on vocal training compared to 11 years of professional training of academic or popjazz vocalists in music schools and colleges 
(and conservatories). In the curricula of acting colleges and universities, vocals are only one among many other disciplines in acting programs and there is as much time devoted to vocals as there is to choreography or art history, for example. Actors cannot manage to master vocal skills at the necessary level in 4-5 years as musical performance art requires much more time to learn.

This factor reduces the quality of mass scenes and forces directors to resort to backing tracks to disguise the actors' inability to sing. Otherwise, producers invite professional singers, often pop stars, to play the leading roles. For example, Philip Kirkorov, Dimash, and Valeria were involved in the musical "One Thousand and One Nights, or the Territory of Love", musicians from "The King and the Jester" participated in the rock musical "Todd", actress Ekaterina Guseva, singer Teona Dolnikova, and actor Andrei Beliavski performed in "Count Orlov", and a whole galaxy of stars appeared in "The Master and Margarita": Valerii Zolotukhin, Andrei Makarevich, Joseph Kobzon, Lolita, and Grigory Leps. This situation is created by the insufficient number of professional actors on the one hand while on the other, not every alumni of the "musical theatre actor" specialty is willing to sing in a choir without having a solo. Unfortunately, here we are dealing with the already established not the best tradition of staging Russian musicals with the lack of the proper culture of performance in this genre. In Russia, musicals have not yet come as long of a way as, for example, in the USA where even in mediocre productions, unknown actors sing, play, and dance on stage so well that the leading and most successful musical theaters of Russia would envy it (Mond, 2011).

The specifics in the development of stage speech skills in vocalists lie in that the basics of the "Stage speech" discipline (proper breathing and articulation, the use of the laws of orthoepy, vocal hygiene) are also mastered with musical accompaniment while in actors' training, this aspect is not emphasized much. The skill of reading poetry and prose to music necessary for a musical actor can also be further complicated by tying the "stage speech" discipline to "stage movement": reading literary material as part of a plastic sketch or staged battle scene is a useful experience for any actor, especially for one in musical theatre.

"Vocals" as a separate discipline is at the first place in the complex of disciplines for future musical actors but takes a secondary position in the training of actors. The modern musical imposes very high requirements to an actor-vocalist since not every single professional pop or even opera singer has the appropriate vocal abilities and technical skills to participate in musical productions. The working curriculum of the "Vocals" discipline (specialty "Actor of Musical Theater Musicals") was developed based on the program for the "Solo Singing" discipline for music colleges and colleges of art. The training provides for the development of students' technical vocal skills to the degree necessary for further professional activity both on the stage of musical theaters and in show-business (Ponomareva, 2015).

In addition to the classical vocal "stance" (work on the support and singing breath, 
vowel alignment, the ability to use the head and chest resonation, mastering the different attacks of the singing sound, mastering strokes, "pure" intonation, cantilena, articulation), a future musical theater actor has to develop the skills of working on vocal pieces of varying complexity in combination with choreography, stage movement, and acting and develop the skills of vocal ensemble performance for which the acting program simply has no place or time. Moreover, a professional vocalist learns different techniques and styles of singing - from folk to pop, while the only thing left for an actor is to acquire a vocal base.

As previously mentioned, an actor in a musical has to be able to sing and dance and, if the play so requires, do it simultaneously. The combination of singing and dancing requires a vocalist to have proper coordination, flexibility, muscular freedom, and excellent physical fitness, not to mention the skills obtained individually in each of these disciplines. It is recommended to work on singing and dancing independently at first and proceed to combine vocals and movements into a single performance after the elements of both disciplines are mastered.

\section{Conclusion}

The process of training future musical actors in music and theater colleges the primary objective of which is the development of the necessary stage skills is carried out through vocalists mastering a set of stage disciplines and actors training in vocals aside from other creative disciplines which leads to the fact that vocalists end up being more prepared for performing in the musical theatre genre compared to actors. The profession of a musical theatre actor is multifaceted, the skills obtained in the course of training can be applied in films, in show business, on television, in drama theatre, however, the utmost importance is, nevertheless, demonstrated by vocal performance skills.

The thorough analysis of the curricula and training programs, as well as observation of the process and results of learning of musical actors, confirm the hypothesis suggesting that vocal training has the utmost importance in training musical actors since a musical, first and foremost, is within the musical-theater genre, therefore, a vocalist can cope with the artistic tasks at a higher professional level compared to an actor who has received vocal training in the process of their education. Moreover, vocational training in musical and theatre universities is more conducive to the development of musical actors' skills compared to the training of film and theater actors.

\section{Study Limitations}

The limitations of the study are due to the fact that not all factors affecting the success of creative activity of actors in musicals are studied yet and the comparative evaluation of the quality of actors' and vocalists' singing is not conducted by all parameters. The subjectivity of opinions and assessments of actors' performances in musicals also put limitations on the study of the designated topic. 


\section{Biodata of Authors}

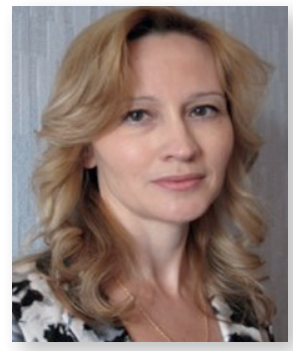

\section{Marina Gennadievna Kruglova, PhD(c)}

Interest of author: Areas of scientific activity: history of music, musical-historical training of students, Russian music in the context of a dialogue of cultures, teaching methods of musicalhistorical disciplines, methods of music education, innovative technologies in music education, inclusive music education, pedagogy of artistic creativity Affiliation: Russian State Social University, Moscow, Russia e-Mail: marisha.krug@mail.ru

ORCID: https://orcid.org/0000-0001-5820-3378 SCOPUS id: https://www.scopus. com/authid/detail.uri?authorld=57211577927 Elibrary: https: / /elibrary.ru/author_ profile. asp?authorid $=560462$

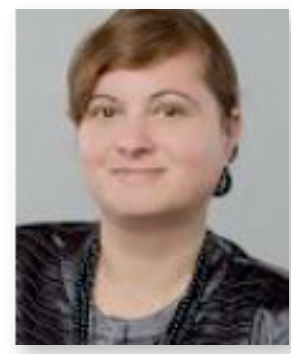

\section{Anna losifovna Shcherbakova, Dr}

Interest of author: Has more than 280 publications, including monographs, textbooks, educational and scientific-methodical manuals, Creator and head of the scientific direction "Philosophy of Music and Music Education". 9 Ph.D. theses were defended under her supervision. Member of dissertation councils for pedagogical sciences Affiliation: Moscow State Institute of Music named after A.G. Schnittke, Moscow, Russia e-Mail: rector@schnittke.ru

ORCID: https://orcid.org/0000-0001-7371-7211 Elibrary: https://elibrary.ru/author_ items.asp?authorid=485752 SCOPUS id: https://www.scopus.com/authid/detail. uri?authorld $=56261037300$

\section{Aigul Gareeva, Postgraduate Student}

Affiliation: Russian State Social University e-Mail: gareeva.detyam@gmail.com ORCID: https://orcid.org/0000-0001-7019-6158

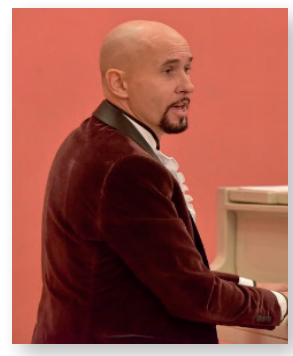

Alexander Ivanovich Vasilenko, Senior Lecturer

Interest of author: Laureate of All-Russian and International competitions Affiliation: Moscow State Institute of Music named after A.G. Schnittke, Moscow, Russia e-Mail: Vasilenko.A.I2@yandex.ru ORCID: https://orcid.org/0000-0003-3845-3585 


\section{References}

Aksenova, S.S., Kruglova, M.G., Ovsyannikova, V.A., Pereverzeva, M.V., Smirnov, A.V. (2020). Musical hermeneutics, semantics, and semiotics. Journal of Advanced Research in Dynamical and Control Systems, 12(3SI), 779-784.

Andrushchenko, E.lu. (2011). Artist miuzikla kak model universalnogo sovremennogo ispolnitelia [Actor in a musical as a model of a universal modern performer]. In: A.V. Krylova (Compl.), Muzykant-ispolnitel v prostranstve mirovoi kultury: tvorchestvo, obrazovanie, upravlenie kareroi. Sbornik statei (pp. 183-193). Rostov-on-Don: Rostov State Conservatory named after S.V. Rachmaninov.

Antipova, A.V. (2019). Osobennosti vokalnoi tekhniki $\mathrm{v}$ miuzikle [Specifics of vocal technique in a musical]. In: S.M. Nizamutdinova (Ed.), Kultura i iskusstvo kak vazhneishaia chast edinogo obrazovatelnogo prostranstva stolichnogo megapolisa. Materials of the Fourth Scientific and Practical Conference of the Institute of Culture and Arts of the Moscow City University (pp. 194-200). Moscow: Perspektiva.

Babiakina, E.P., Babiakina, V.S. (2018). Moskovskii teatralnyi kolledzh: istoriia i perspektivy razvitiia [Moscow Theater College: history and prospects of development]. In: L.V. Buraya (Ed.), Regionalnoe obrazovanie i kultura: istoriia, sovremennost, perspektivy. Materials of the XIX Interregional Scientific and Practical Conference dedicated to the 65th anniversary of Belgorodchina (pp. 52-54). Belgorod: ROSASb.
Chaika, A.A., lushchenko, N.S. (2020). Osnovnye printsipy raboty artistavokalista $v$ muzykalnom teatre [Basic principles of a vocalist's work in a musical theater]. In: M.V. Pereverzeva (Ed.), Kultura, iskusstvo, obrazovanie $v$ sovremennom mire: voprosy teorii $\mathrm{i}$ praktiki. Sbornik nauchnykh trudov (pp. 179-184). Magnitogorsk: CT "Buki-Vedi".

Feist, G.J. (2019). An evolutionary model of artistic and musical creativity. In: C. Martindale, P. Locher, V. Petrov (Eds.), Evolutionary and neurocognitive approaches to aesthetics, creativity, and the arts (pp. 15-30). Amityville, NY: Baywood Publishing.

Hargreaves, M.J.A. (2003). The development of artistic and musical competence. In: I. Deliège, J. Sloboda (Eds.), Musical beginnings. Origins and development of musical competence (pp. 145-170). Oxford: Oxford University Press.

Klabukova, A.V. (2016). Nekotorye printsipialnye podkhody $k$ razvitiiu stsenicheskogo masterstva vokalistov $v$ vuzakh kultury [Some fundamental approaches to the development of vocalists' stage skills in the universities of culture]. Bulletin of the Moscow State University of Culture and Arts, 5(73), 207214.

Komarnitskaia, T.A. (2020). Osobennosti prepodavaniia muzykalnykh distsiplin studentam bakalavriata, obuchaiushchimsia po spetsialnosti "Artist teatra i kino" v Mezhdunarodnoi teatralnoi akademii (MIUR, Rim) [Specific features of teaching musical disciplines to undergraduate students in the "Theatre and Film Acting" specialty 
at the International Theater Academy (MIUR, Rome)]. In: R.G. Shitikova (Ed.), Muzykalnaia kultura glazami molodykh uchenykh. Sbornik nauchnykh trudov (pp. 217-220). Saint Petersburg: Asterion.

Kotomin, B.A. (2007). Metodika prepodavaniia teatralnykh distsiplin: Uchebnoe posobie dlia studentov po spetsialnosti "Sotsialno-kulturnaia deiatelnost i narodnoe khudozhestvennoe tvorchestvo", spetsializatsii "Teatralnoe tvorchestvo" [Methodology of teaching theatrical disciplines: Textbook for students majoring in "Social and Cultural Activity and Folk Artistic Creativity", specialization "Theatrical Creativity"]. Tambov: Tambov State Music and Pedagogical Institute named after S. V. Rachmaninov, 146 p.

Mindrin, S.V., Sukhanova, T.B. (2017). Spetsialnost "Akterskoe iskusstvo" v konservatorii i perspektivy razvitiia muzykalno-stsenicheskoi kultury Rossii [Specialty "Acting Art" in a conservatory and prospects for the development of music and stage culture in Russia]. Muzykalnoe obrazovanie i nauka, 1(6), 28-31.

Mond, O.-L. (2011). Usloviia i faktory vershinnykh dostizhenii ispolnitelei miuzikla [Conditions and factors of musical theatre performers' top achievements]. In: Problems and prospects of the development of education. Materials of the International Scientific Conference (pp. 168-171). Perm: Merkurii.

Pereverzeva, M.V., Kats, M.L., Ovsyannikova, V.A., Aksenova, S.S., Yushchenko, N.S. (2020a). Technology and innovation in schoolchildren training:
Development of musical and acting skills. Universal Journal of Educational Research, 8(7), 2766-2771.

Pereverzeva, M.V., Umerkaeva, S.S., Anufrieva, N.I., Kats, M.L., Kazakova, I.S. (2020b). Interdisciplinary approach to the mastering of the music of the 20th century. Journal of Advanced Research in Dynamical and Control Systems, 12(3SI), 772-778.

Poliakova, A.A. (2011). Rabota artistavokalista $v$ miuzikle [The work of a vocalist in a musical]. In: lu.lu. Andreeva, I.E. Rakhimbaeva (Eds.), Personality development by means of art. Proceedings of the VIII International Scientific-Practical Conference of Students, Bachelors, Masters, and Young Scientists (pp. 318325). Saratov: Saratovskii istochnik.

Ponomareva, N.lu. (2015). Formirovanie professionalnykh kachestv artista miuzikla na urokakh vokala [The formation of professional qualities of a musical theatre artist at the vocal lessons]. Trudy Sankt-Peterburgskogo gosudarstvennogo instituta kultury, 209, 105-109.

Starodubtsev, V.V. (2011). Metodika obucheniia masterstvu aktera i rezhissury opery [Methods of teaching acting and directing opera]. Dissertation summary. Russian Institute of Theatre Arts GITIS, Moscow, Russia, 21 p.

Usov, V.V. (2013). O sozdanii vokalnostsenicheskogo obraza [On the creation of a vocal and scenic image]. Mir nauki, kultury, obrazovaniia, 3(40), 307-308.

Voznesenskaia, M.S. (2017). Sovremennyi otechestvennyi miuzikl: osobennosti 
raboty pevtsa-aktera nad roliu [Modern Russian musical: specific features of a vocalist-actor's work on the part]. In: N.S. Bazhanov (Ed.), Ispolnitelskoe iskusstvo: istoriia, teoriia, metodologiia. Proceedings of the All-Russian Scientific and Practical Conference (pp. 94-102). Novosibirsk: Novosibirsk State Conservatoire named by M.I. Glinka.

Zimina, I.F., Novgorodtseva, S.S. (2019). Miuzikl kak sposob formirovaniia transprofessionalnykh kompetentsii u studentov iskusstv [Musical as a means of forming transprofessional competencies in art students]. In: E.F. Zeer, V.S. Tretiakova (Eds.), Transprofessionalizm kak prediktor sotsialno-professionalinoi mobilnosti molodezhi: Materials of the All-Russian conference (with international participation) (pp. 29-32). Yekaterinburg: Russian State Vocational Pedagogical University. 
Vocalist or actor: which one is better prepared to perform in the musical theatre genre? 